\title{
Determination of Manganese in Tap Water by a New Extraction- photometric Method
}

\author{
Nushiravan Khankishi Rustamov and Gulu Ganimat Abbasova*
}

Laboratory of Analytical Chemistry, ANAS Institute of Chemical Problems named after acad. M.F.Nagiyev, 29-H.Javid ave., Baku-AZ1143, Azerbaijan

\begin{abstract}
The heteroligand complex of manganese with 1,10-phenantroline and o-nitrobenzolazosalicylic acid have been investigated by spectrophotometric method. The condition of complexing and extraction, physical-chemical and analytical characteristics of this complex have been found. Complex formation is observed in the pH range 5-11. Extraction constant was found as $5.3 \times 10^{12}$, stability constant was found as $\lg \beta_{K}=9.03 \pm 0.03$. Molar absorptivity is $\varepsilon=(1.36 \pm 0.08)$ $\times 10^{4}$. Beer's law is obeyed in the range of $1.0-22.5 \mathrm{mkq}$ manganese(II).

The extraction-photometric methods of manganese determination have been worked out. The influence of diverse ions on determination of manganese(II) has been studied. The proposed method was applied successfully to determine amount of manganese in tap water.
\end{abstract}

Keywords: Extraction-photometric determination; Complexing; Manganese; 1,10-Phenantroline; Chromogenic organic reagent

\section{Introduction}

Manganese is considered to be the $12^{\text {th }}$ most abundant element in the biosphere. Its concentration in earth crust reaches as high as $0.098 \%$. It is widely distributed in soil, water, sediment and biological materials. Manganese has accumulative properties. Due to this accumulating in the organism chronic manganese excess affects the central nervous system, with the symptoms resembling those of Parkinson's disease [1].

Various methods for the determination of manganese with chromogenic organic reagents have been reported. The reagents suggested for determination of manganese include: toluidine blue [2], Mordant brown 33 [3], phenoxazine [4], eosin [5].

In the literature there is data on the use of o-nitrobenzolazosalicylic acid for determination of nickel, zinc, ferrous, cobalt [6-9]. But no data about determination of manganese with o-nitrobenzolazosalicylic acid can be found in the literature.

The heteroligand complex of manganese(II) has been investigated with 1,10-phenantroline (Phen) from aromatic diamines and with o-nitrobenzolazosalicylic acid (oNBASA) from chromogenic organic reagents and the new rapid, simple and sensitive extraction-photometric method of manganese determination with these reagents have been worked out by us.

\section{Experimental}

\section{Instruments}

Absorption measurements were collected on a SF-46 spectrophotometer or KFK-3 photoelectrocolourimeter using $1 \mathrm{~cm}$ cuvette. The $\mathrm{pH}$-meter EV-74 is used for $\mathrm{pH}$ measurements.

\section{Reagents}

Stock solution of $1.52 \times 10^{-2} \mathrm{M}$ manganese(II) was prepared from $\mathrm{MnCl}_{2} \cdot 4 \mathrm{H}_{2} \mathrm{O}$ salt with qualification "p.f.a." (Pure for analysis) and quantity of manganese standardized gravimetrically [10]. Working solution of $4.5 \times 10^{-4} \mathrm{M}$ manganese(II) was prepared by dilution of stock solution with distilled water. Solution of oNBASA with $5 \times 10^{-3} \mathrm{M}$ concentration was prepared by dissolving the required amount in water, in which $\mathrm{pH}$ was arrived to 12 in advance. Solution of Phen with $1 \times 10^{-2}$
M concentration was prepared by dissolving the required amount of preparate which was the production in firm "Chemapol" in 50\% ethanol (by volume). Universal or borate buffer solutions or $0.1 \mathrm{M} \mathrm{CH} 3 \mathrm{COOH}$ and $\mathrm{NaOH}$ solutions were used for obtaining appropriate $\mathrm{pH}$.

\section{Procedure}

Appropriate amount of solutions of Phen and oNBASA have been added to the definite amount of solution of manganese(II) in test-tube with stoppers or in separator funnel. Then total volume has been diluted to $10 \mathrm{ml}$ by adding of buffer solution. The mixture has been shaked for 1 minute with adding of $5 \mathrm{ml}$ solvent. Colored extract has been transferred to the cuvette when the phases separated and absorbance has been measured relative to the water. The analogical experiment has been carried out without manganese and absorbance of the extract of reagent has been measured also relative to the water.

\section{Results and Discussion}

Investigations show that the derivatives of salicylic acid form colored complexes with transition metals [6-9] and this can be used in developing an extraction-photometric method for the determination of these metals, also of manganese(II).

\section{Condition of complexing and spectral characteristics}

The absorption spectra of chromogenic organic reagent and complex of manganese with Phen and oNBASA obtained in the $\mathrm{pH}$ range $5,0-11,0$ of the aqueous phase showed that $\mathrm{Mn}$ (II) with Phen and oNBASA forms a complex one composition. The absorption spectra of solutions of reagent and the complex show that the maximum

*Corresponding author: Gulu Ganimat Abbasova, Laboratory of Analytical Chemistry, ANAS Institute of Chemical Problems named after acad. M.F.Nagiyev 29-H.Javid ave., Baku-AZ1143, Azerbaijan, Tel: +994557434323; E-mail: veliyeva_g@mail.ru

Received October 11, 2013; Accepted December 30, 2013; Published January 02,2014

Citation: Rustamov NK, Abbasova GG (2014) Determination of Manganese in Tap Water by a New Extraction-photometric Method. J Environ Anal Toxicol 4: 205. doi: 10.4172/2161-0525.1000205

Copyright: (C) 2014 Rustamov NK, et al. This is an open-access article distributed under the terms of the Creative Commons Attribution License, which permits unrestricted use, distribution, and reproduction in any medium, provided the original author and source are credited. 
absorbance takes place at $\mathrm{pH} 10$ (Figure 1) and wavelength of $370 \mathrm{~nm}$ have been selected for the present work (Figure 2).

The influence of the concentration of Phen and oNBASA was studied. The optimal concentration of Phen and oNBASA for formation of the complex was found to be $6 \times 10^{-4} \mathrm{M}$ and $2.5 \times 10^{-4} \mathrm{M}$, respectively.

Excess amount of Phen and oNBASA does not affect the formation and extraction of the complex. Because, in the condition of complexing the carboxyl group of the chromogenic organic reagent is ionized and charged form is preferably in the aqueous phase. The heteroligand complex of $\mathrm{Mn}(\mathrm{II})$ with Phen and oNBASA was extracted with chloroform and dichloroethane. Optimal volume of aqueous and organic phase was found to be $25-50$ and $5 \mathrm{ml}$, respectively. Mn-PhenoNBASA complex is formed immediately after adding the reagents and extraction equilibrium is achieved by shaking up 1 minute.

The sequence of reagents to be added does not affect the complex formation and extraction. The intensity of color of the complex does not change depending on time and stable during the day.

\section{Content of complex}

The stoichiometric coefficients of the complexing were established. The molar ratio Mn: Phen: oNBASA was proved by the method of straight line and crossing the lines [11]. The results for the light absorption of the extracts at $370 \mathrm{~nm}$ showed that the complex was formed at a ratio Mn: Phen: oNBASA=1:2:2. By the method of Nazarenko [12] was established that the complexing form of manganese are the ions $\mathrm{Mn}^{+2}$. The same amount of complex two times was extracted consistently and extraction percentage was found: $98.76 \%$.

Extraction constant was found as $5.3 \times 10^{12}$, stability constant was found as $\lg \beta \mathrm{K}=9.03 \pm 0.03$.

By the method of Komar [11] was found molar absorptivity is $\varepsilon=(1.36 \pm 0.08) \times 10^{4}$. Beer's law is obeyed in the range of $1.0-22.5 \mathrm{mkq}$ manganese(II).

\section{Effect of diverse ions}

In order to assess the usefulness of the proposed method the influence of strange ions on the extraction-photometric determination of manganese was studied. The tolerance of the method of foreign

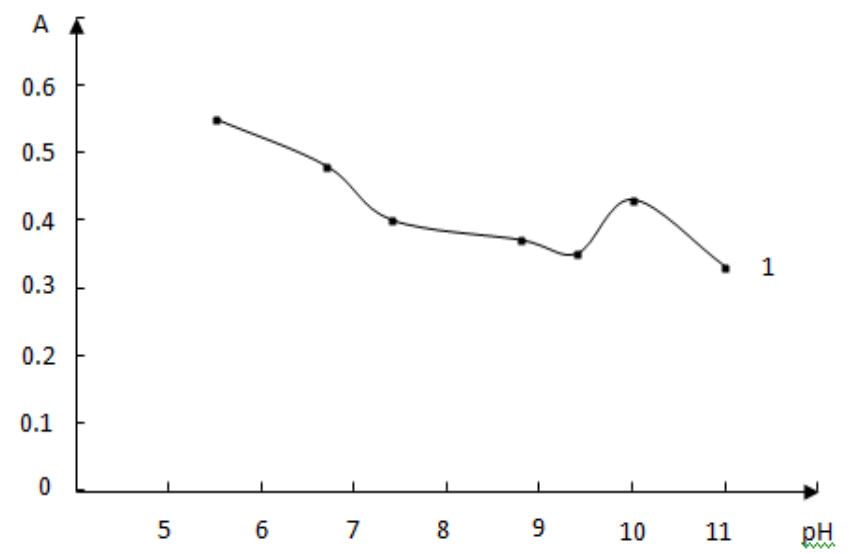

Figure 1: The influence of $\mathrm{pH}$ of the aqueous phase in the formation and extraction of the complrx of manganese (II) with Phen and oNBASA, $\left(\mathrm{C}_{\mathrm{Mn}}=2.23\right.$ $\times 10^{-5} \mathrm{M}$, CPhen $\left.=2 \times 10^{-4} \mathrm{M}, \mathrm{C}_{\mathrm{NBASA}}=1.5 \times 10^{-4} \mathrm{M}, \mathrm{KFK}-3, \lambda=400 \mathrm{~nm}\right)$

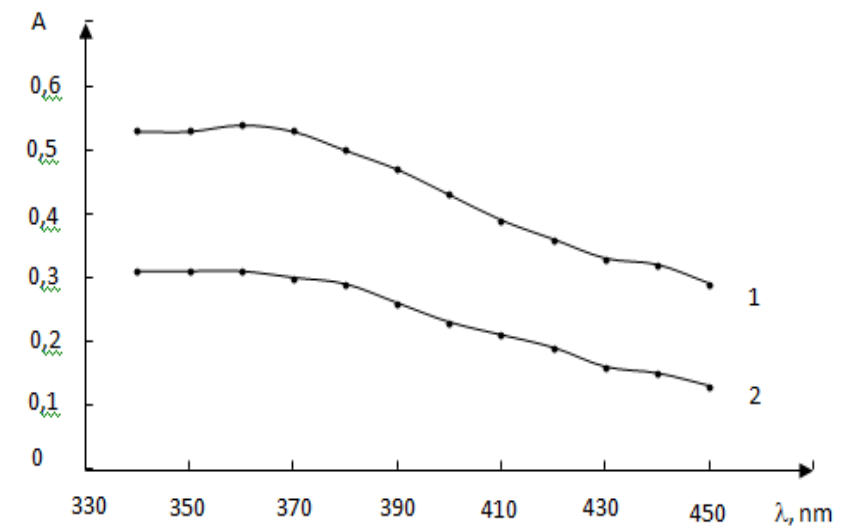

Figure 2: Absorption spectra of extract of complex (1) and $\left(\mathrm{C}_{\mathrm{Mn}}=2.23 \times 10^{-5} \mathrm{M}\right.$ CPhen $=2 \times 10^{-4} \mathrm{M}, \mathrm{C}_{\text {oNBASA }}=1.5 \times 10-4 \mathrm{M} \mathrm{KFK}^{-3}, \lambda=400 \mathrm{~nm}$ ).

ions was investigated with solutions containing $10 \mathrm{mkg} \mathrm{Mn}(\mathrm{II})$ per $25 \mathrm{ml}$ and various amounts of foreign ions. Mn(II) was determined as $\mathrm{Mn}(\mathrm{Phen})_{2}(\mathrm{oNBASA})_{2}$ under the optimum conditions as described in the experimental procedure. The determination of manganese was possible in the presence of $\mathrm{Li}(\mathrm{I}), \mathrm{Na}(\mathrm{I}), \mathrm{K}(\mathrm{I}), \mathrm{Ca}(\mathrm{II}), \mathrm{Sr}(\mathrm{II}), \mathrm{Ba}(\mathrm{II})$, Cd(II), Hg(II), AlIII), Ti(IV), Zn(II), V(V), Cr(III), Mo(VI), Ni(II), $\mathrm{Pb}(\mathrm{II}), \mathrm{As}(\mathrm{V}), \mathrm{Mg}(\mathrm{II}), \mathrm{Bi}(\mathrm{III}), \mathrm{In}(\mathrm{III}), \mathrm{Ge}(\mathrm{IV})$. But Co(II), Zn(II), Cu(II), $\mathrm{Fe}(\mathrm{III}), \mathrm{Ag}(\mathrm{I})$ ions were influenced on the extraction-photometric determination of manganese(II).

\section{Determination of manganese(II) in tap water}

Water sample was taken in the flask 21 and was evaporated to dryness. Dry residue was dissolved in a buffer solution with $\mathrm{pH} 10$ and by filtering was transferred to a $50 \mathrm{ml}$ flask. Aliquot part was transferred to the separator funnel or test-tube. $2 \mathrm{ml}$ buffer solution with appropriate $\mathrm{pH}, 0.6 \mathrm{ml}$ Phen and $0.5 \mathrm{ml}$ oNBASA was added. Then was diluted by the same buffer solution to $10 \mathrm{ml}$ and was extracted with chloroform for 1 minute. Absorbance was measured in SF-46 in the cuvette of $1 \mathrm{~cm}$ when the phases separated. Amount of manganese was determined from the calibration graph. Amount of manganese have been determined in tap water by the proposed method: $0.018 \pm 0.009$ $\mathrm{mkg} / \mathrm{ml}$.

\section{Conclusions}

At the first time the heteroligand complex of manganese(II) has been investigated with 1,10-phenantroline (Phen) and o-nitrobenzolazosalicylic acid (oNBASA) from chromogenic organic reagents. The new rapid, simple and sensitive extraction-photometric method of manganese determination with these reagents have been worked out and applied to determination of manganese(II) in tap water by us.

\section{References}

1. Mortimer JA, Borenstein AR, Nelson LM (2012) Associations of welding and manganese exposure with Parkinson disease: Review and meta-analysis. Neurology 79: 1174-1180.

2. Kostova D (2010) Determination of manganese by a new spectrophotometry method using toluidine blue. Journal of analytical chemistry 65: 159-163.

3. Seleim MM, Abu-Bakr MS, Hashem EY, El-Zohry EM (2009) Spectrophotometric determination of manganese (II) with Mordant Brown 33 in the presence of Tween 20 in some foods. Canadian Journal of Analytical Sciences and Spectroscopy 54: 93-101. 
Citation: Rustamov NK, Abbasova GG (2014) Determination of Manganese in Tap Water by a New Extraction-photometric Method. J Environ Anal Toxicol 4: 205. doi: 10.4172/2161-0525.1000205

4. Mghimi M, Syed AA, Al-okab RA, Taghartapeh MR (2010) Application of electrophilic coupling reaction as a novel spectrophotometric methods for the determination of manganese. International Conference on Biology, Environment and Chemistry 1: 337-340.

5. Rauf MA, Ikram M, Ahmad M (2002) Spectrophotometric studies of ternary complexes of vanadyl, manganese, and iron with o-phenanthroline and eosin. Journal of trace and microprobe techniques A 20: 171-180.

6. Lavrukhina AK, Yukina LV (1974) Analiticheskaya khimiya margantsa. Nauka, Moscow, Russia, 315.

7. Rustamov NKh, Mustaphayev NM, Rustamova UN (2004) J Chemistry and chemical technology 47: 15-20.
8. Rustamov NKh, Bayramova TD (2005) Azerbaijan Chemical Journal 4: 97-99.

9. Rustamov NKh, Aliyeva AA, Agamaliyeva MM (2003) Azerbaijan Chemical Journal 2: 54-57.

10. Rustamov NKh, Abbasova GG, Mustaphayev NM (2011) J Chemical Problems 3: 495-497.

11. Bulatov MI, Kalinkin IP (1968) Prakticheskoe rukovodstvo po fotokolorimetricheskim i spektrofotometricheskim metodam analiza (Practical Guide on Photocolorimetric and Spectrophotometric Methods of Analysis), Leningrad: Khimiya.

12. Nazarenko VA (1969) Proceedings of the Committee on Analytical Chemistry. Nauka, Moscow, Russia, 17: 12. 